\title{
Mollusk communities differ between microenvironments within a shallow lake in the Pampean Region, Argentina
}

\author{
Eleonor Tietze ${ }^{1, \mathbb{Q}}$; Paula A. Cristini² \& Sebastián I. Grondona ${ }^{1,3}$ \\ ${ }^{1}$ Instituto de Investigaciones Marinas y Costeras (IIMyC, CONICET - Universidad Nacional de Mar del Plata). Mar del \\ Plata, Argentina. ${ }^{2}$ Instituto en Investigaciones en Ciencia y Tecnología de los Materiales (INTEMA, CONICET - Universidad \\ Nacional de Mar del Plata), División Electroquímica Aplicada. Mar del Plata, Argentina. ${ }^{3}$ Instituto de Geología de Costas y del \\ Cuaternario (IGCyC, Universidad Nacional de Mar del Plata - CIC Provincia de Buenos Aires). Mar del Plata, Argentina.
}

\begin{abstract}
Aвstract. The aim of this study is to compare the faunistic mollusk composition at a local scale, in different sites within a shallow lake, and to evaluate the relation between abundance and richness of mollusks and the environmental variables. The distribution of the mollusks within the water body was patchy but not random. Three of the sites were deeper, mainly dominated by emergent macrophytes and were characterized by the dominance of the gastropods Heleobia parchappii, Physa acuta and Uncancylus concentricus. In contrast, the other two sites were dominated by Biomphalaria peregrina and the bivalve Musculium argentinum, and were characterized by lower depth and $\mathrm{pH}$, and higher vegetation diversity and water temperature. This study evidences the patchiness of freshwater mollusk species in a Pampean shallow lake, where environmental factors partially explain the local distribution within the lake.
\end{abstract}

[Keywords: freshwater mollusks]

Resumen. Comunidades de moluscos difieren entre microambientes en un lago somero de la región pampeana, Argentina. El objetivo de este trabajo es comparar la distribución de los ensambles de moluscos en diferentes sitios dentro de un lago somero pampeano y evaluar la relación que existe entre la abundancia y la riqueza de moluscos y las variables ambientales. Los moluscos mostraron una distribución en parches, pero no azarosa. Tres de los sitios que eran más profundos y que estaban dominados por macrófitas emergentes estuvieron caracterizados por mayores abundancias de los gasterópodos Heleobia parchappii, Physa acuta y Uncancylus concentricus. En contraste, los otros dos sitios que estuvieron caracterizados por menores profundidades, menores $\mathrm{pH}$, mayor diversidad de vegetación y temperaturas del agua más altas estuvieron dominados por Biomphalaria peregrina y por el bivalvo Musculium argentinum. Este estudio evidencia la distribución en parches de moluscos dulceacuícolas en lagos someros de la ecorregión pampeana donde las variables ambientales explican de forma parcial la distribución local dentro del lago.

[Palabras clave: moluscos dulceacuícolas]

\section{INTRODUCTION}

One of the main objectives of community ecology is to explain patterns of species composition and distributions. Several variables are responsible for the observed patterns, and the requirements of the species are especially important at smaller scales (Horsak et al. 2007). Freshwater mollusks play an important role in aquatic ecosystems, providing food for many fish species (McMahon and Bogan 2001; García et al. 2006; Fagundes et al. 2008) and vertebrates (Cummins and Bogan 2006; Maltchik et al. 2010). When environmental factors, which determine the mollusk richness and distribution in continental waters, were investigated, water hardness, conductivity, $\mathrm{pH}$, substrates, vegetation and biotic interactions were reported as the most important environmental factors affecting mollusk distribution (Dillon 2000; Horsák et al. 2007).

Editora asociada: Irina Izaguirre
The Pampean plain represents one of the largest wetland areas of South America (Diovisalvi et al. 2015; Viglizzo et al. 2011). The low morphogenetic energy of the flat landscape combined with their occurrence in humid to sub-humid climates results in a variety of freshwater bodies (e.g., ponds, shallow lakes and marshes) (Geraldi et al. 2011). Freshwater mollusks of this region are an important component of macroinvertebrate assemblages and present a small number of species (1-5; mostly snails) and low regional variability (low beta-diversity) (Tietze and De Francesco 2010, 2012; De Francesco et al. 2013). Therefore, mollusks species are widely distributed due to the similar environmental characteristics exhibited by the habitats as consequence of the environmental homogeneity of the area. However, some differences between sites related to the microhabitat availability were found in a previous study (Tietze and De Francesco 2010). 
In the present study we hypothesized that environmental variables influence the composition of mollusk assemblages at site scale. Thus, the aim of the present contribution was to compare the faunistic mollusk composition at a local scale in different sites within a shallow lake, and to evaluate the relation between abundance and richness of mollusks and the environmental variables. The study was performed during a year to capture a high variability in the environmental variables, mollusk presence and species abundance.

\section{Materials And Methods}

\section{Study area and sites}

The study was carried out in the shallow lake Nahuel Rucá, a Pampean water body located near Mar del Plata city (NR; 3737'21'” S $57^{\circ} 25^{\prime} 42^{\prime \prime} \mathrm{W}$ ) (Figure 1). Pampeanlakes are very shallow (about $2 \mathrm{~m}$ of mean depth), permanent or temporary, and lack thermal stratification except for short periods of time (Quirós and Drago 1999). Owing to their shallowness, the dynamics of Pampean lakes are tightly tied in with climate conditions, and the annual precipitation and evaporation volumes are within the same order of magnitude as their hydric volumes (Fernández Cirelli and Miretzky 2004; Diovisalvi et al. 2015). Their low depths favor water-sediment interaction by wind action, especially during periods with lower precipitation.
The climate in the region is temperate humid or subhumid with a mean annual temperature of $15{ }^{\circ} \mathrm{C}$, with warm summers and mild winters and a mean annual precipitation of 1100 mm (Feijoó and Lombardo 2007). The water residence time is highly variable due to the periodic alternation between flood and drought periods.

\section{Data collecting}

We sampled five sites within NR for eleven months between August 2014 and September 2015. The sites were chosen in order to represent different microenvironments within the same water body. Sites 1 and 2 were behind the macrophyte ring of bulrush Schoenoplectus californicus, which characterize Pampean lakes. Site 3 was an open site on the shore with the same emergent macrophyte, but distributed in patches and with submerged macrophytes also present in the site. Sites 4 and 5 were also sites on the shore of the lake but with lower depths. Both sites presented S. californicus as rooted emergent macrophyte, free-floating macrophytes (Azolla sp., Lemnaceae) and also vegetation that characterize the transitional zone between aquatic and terrestrial habitats. During December the water level of the lake decreased, disabling the possibility of sampling S4 and S5 because they got dry. Since January the water level increased slowly. Usually, Pampean shallow lakes decrease its size naturally during summer due to evaporation, but during the sampling year a floodgate that controls water level of the

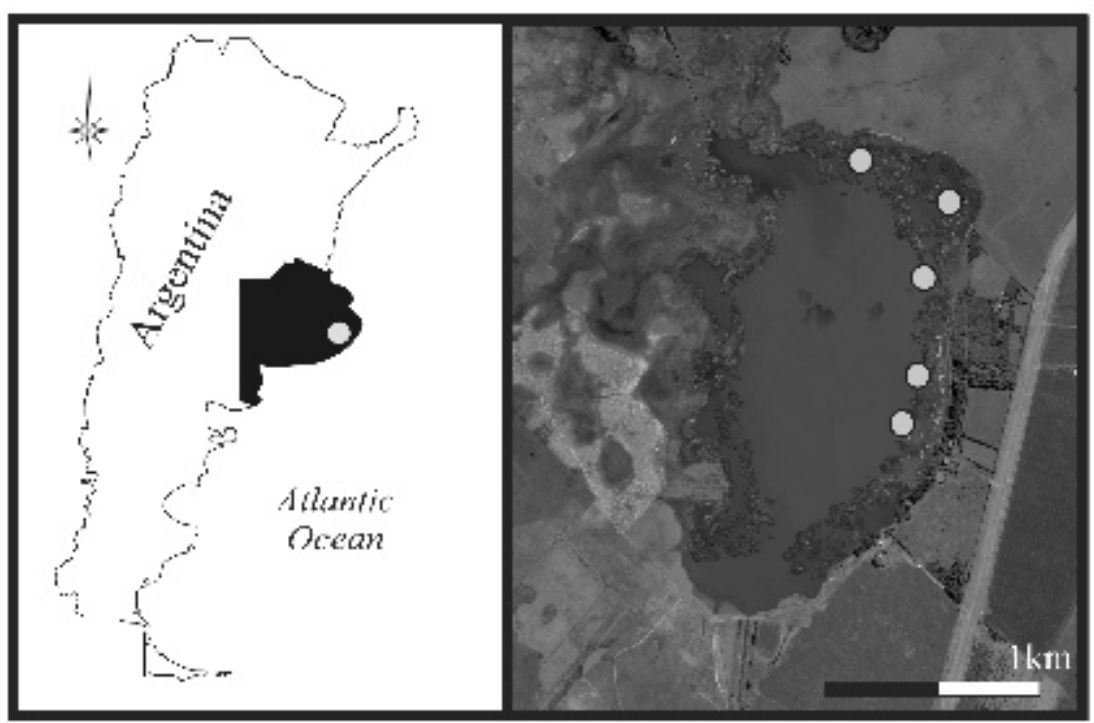

Figure 1. Location of the study area: Nahuel Rucá shallow lake.

Figura 1. Mapa del área de estudio: laguna Nahuel Rucá. 
lake NR was lost and the decrease was higher than most of the years.

Living mollusks were searched among the emergent, free-floating and submerged vegetation, under stones, and on the substratum. Sites were delimited using a quadrant with a sampling area of $5 \mathrm{~m}^{2}$ and a penetration depth of few centimeters $(\sim 5$ $\mathrm{cm})$. According to Cummins (1994) and Martello et al. (2006), this sampling area is adequate to the low abundance of mollusks in freshwater habitats. Mollusks were collected both manually (picking up by hand) and with the aid of sieves $(0.5 \mathrm{~mm})$. Sampling was carried out for time of effort (number of snails caught per hour) following Martín et al. (2001), and conducted by the same person to avoid sampling bias. The time between the different substrata or methods is not standardized, depends on each site and the type of substrata present. Mollusk species were identified using external (shell) and internal (soft parts) morphology, and counted. Mollusk identification was based on Castellanos and Fernández (1976), Gaillard and Castellanos (1976), Fernández (1981a b), Castellanos and Gaillard (1981), Rumi (1991), and Castellanos and Landoni (1995).

Water temperature was measured on the field at each sampling site. To assess chemical parameters one subsurface water sample (1 L) was taken at each site. Water samples were collected in polyethylene bottles and stored in ice until they were transported to the laboratory. Water samples were analyzed within 15 days of collection for concentrations of sodium $\left(\mathrm{Na}^{+}\right)$, phosphorous $\left(\mathrm{P}^{-5}\right)$, chloride $\left(\mathrm{Cl}^{-}\right)$, phosphate $\left(\mathrm{PO}_{4}^{3-}\right)$, carbonate $\left(\mathrm{CO}_{3}^{-2}\right)$, bicarbonate $\left(\mathrm{HCO}_{3}^{-}\right)$, magnesium $\left(\mathrm{Mg}^{2+}\right)$, calcium $\left(\mathrm{Ca}^{2+}\right)$, silica $\left(\mathrm{SiO}_{2}\right)$ and hardness $(\mathrm{mg} /$ $\mathrm{LCaCO}_{3}$ ). Chemical analyses were performed applying standard methods (APHA 1992).

\section{Statistical analyses}

Species richness and dominance patterns of malacocoenoses were described in individual sites per month. Species diversity in individual sites per month was estimated with ShannonWiener index $\left(\mathrm{H}^{\prime}\right)$ (Magurran 1988) and the dominance with Simpson index (1-D) (Simpson 1949).

Differences in species composition between sites were tested using the PERMANOVA procedure to a Bray-Curtis dissimilarity matrix based on squared rooted mollusk abundances. The design was a one-way PERMANOVA with Site as a factor with five levels (S1, S2, S3, S4, S5). The PERMANOVA is a non-parametric procedure that incorporates permutations to test for significance, thereby not relying on normality assumptions (Anderson 2001). The design was run using a permutation of residuals under a full model (9999 permutations) with Type III (partial) sums of squares. Terms found to be significant in the full model were examined individually using pair-wise tests of the PERMANOVA test statistic with 9999 random permutations. Multivariate patterns were shown by nonmetric multidimensional scaling (nMDS) plot (Clarke and Warwick 2001). Although the PERMANOVA allows making a posteriori comparisons among levels of factors or groups, it does not identify which variables are responsible for the differences found. Thus, a Similarity Percentages Analysis (SIMPER) (Clarke 1993) was performed in order to identify which species contributed to the differences found with the PERMANOVA analysis.

The relationship between environmental variables and mollusk abundances was investigated using distance-based multivariate analysis for a linear model (DISTLM) (Anderson 2005). For this analysis a draftsman plot was used to identify possibly strong correlated variables and the variables were log-transformed. Multivariate analyses were performed using the software PERMANOVA + for PRIMER (Plymouth Routines in Marine Ecological Research) (v. 5.2) (Anderson et al. 2008).

\section{RESULTS}

Water temperature varied between $14^{\circ}$ and $25{ }^{\circ} \mathrm{C}$, approximately. The temperature was higher than $20^{\circ} \mathrm{C}$ from August to March and then decreased to approximately $16^{\circ} \mathrm{C}$ between April and September 2015. Sites were characterized by alkaline $\mathrm{pH}$, which varied between 8.20 (October 2014) and 9.57 (May 2015). The percentage of organic matter varied between $8.20 \%$ in December and $16.74 \%$ in August 2014 (Table 1), and was similar between sites, with the exception of S3 where was lower than at the other sites (Figure 2).

A total of 10 mollusk species (9 gastropods and 1 bivalve) and a total of 3012 individuals were recorded (Table 2, Figure 3). In terms of abundance (overall abundance during the year) the species recorded were: Heleobia 
Table 1. Environmental variables measured at the different sites (mean, min=minimum and max=maximum) during the study. Concentrations of ions are expressed in $\mathrm{mg} / \mathrm{L}$, humidity $(\%)$, organic content (\%, estimated using the losson-ignition method), water temperature $\left({ }^{\circ} \mathrm{C}\right)$ and hardness $\left(\mathrm{mg} / \mathrm{L}\right.$ of $\left.\mathrm{CaCO}_{3}\right)$.

Tabla 1. Variables ambientales medidas en los distintos sitios (medias, min=mínimas y máx=máximas) durante el período de estudio. Concentraciones de iones expresadas en $\mathrm{mg} / \mathrm{L}$, humedad $(\%)$, contenido de materia orgánica (\%, estimado por medio del método de pérdida por ignición), temperatura del agua $\left({ }^{\circ} \mathrm{C}\right)$ y dureza $\left(\mathrm{mg} / \mathrm{L} \mathrm{de} \mathrm{CaCO}_{3}\right)$.

\begin{tabular}{|c|c|c|c|c|c|c|c|c|c|c|c|c|c|c|c|}
\hline \multirow{2}{*}{ Variable } & \multicolumn{3}{|c|}{ S1 } & \multicolumn{3}{|c|}{ S2 } & \multicolumn{3}{|c|}{ S3 } & \multicolumn{3}{|c|}{ S4 } & \multicolumn{3}{|c|}{ S5 } \\
\hline & Mean & Min & Max & Mean & Min & Max & Mean & Min & Max & Mean & Min & Max & Mean & Min & Max \\
\hline Carbonates & 20.6 & 0.0 & 81.5 & 30.9 & 0.0 & 114.0 & 28.3 & 0.0 & 81.5 & 20.4 & 0.0 & 81.5 & 18.4 & 0.0 & 102.0 \\
\hline Bicarbonates & 668.1 & 278.0 & 1083.0 & 622.3 & 313.0 & 895.0 & 677.7 & 313.0 & 865.0 & 633.7 & 265.0 & 995.0 & 704.7 & 200.0 & 974.0 \\
\hline Chloride & 282.0 & 102.3 & 402.0 & 305.0 & 95.0 & 424.0 & 285.5 & 102.3 & 388.0 & 321.0 & 137.0 & 570.0 & 317.0 & 161.0 & 461.0 \\
\hline Hardness & 293.0 & 152.0 & 434.0 & 293.1 & 152.0 & 352.0 & 304.9 & 162.0 & 444.0 & 301.3 & 147.0 & 458.0 & 285.3 & 134.0 & 367.0 \\
\hline Calcium & 56.6 & 12.0 & 102.0 & 57.7 & 13.0 & 110.0 & 66.7 & 10.0 & 132.0 & 72.5 & 8.0 & 172.0 & 61.0 & 10.0 & 112.0 \\
\hline Magnesium & 35.0 & 5.8 & 64.0 & 33.3 & 12.4 & 59.0 & 29.8 & 7.4 & 50.1 & 25.5 & 6.7 & 58.5 & 28.5 & 4.6 & 66.0 \\
\hline Phosphates & 9.0 & 3.4 & 19.5 & 9.8 & 4.3 & 19.8 & 8.8 & 4.4 & 15.6 & 11.4 & 3.9 & 20.1 & 14.6 & 5.9 & 31.2 \\
\hline Phosphorous & 2.7 & 1.1 & 6.0 & 2.8 & 1.4 & 6.5 & 2.6 & 1.4 & 5.0 & 3.5 & 1.3 & 6.5 & 4.6 & 1.6 & 10.3 \\
\hline Sodium & 253.5 & 25.0 & 450.0 & 229.6 & 46.0 & 360.0 & 268.2 & 35.0 & 450.0 & 242.5 & 25.0 & 420.0 & 219.0 & 20.0 & 380.0 \\
\hline Potassium & 19.1 & 1.0 & 40.0 & 17.1 & 3.5 & 36.0 & 16.6 & 3.0 & 28.0 & 18.8 & 2.0 & 31.0 & 20.6 & 2.0 & 38.0 \\
\hline $\begin{array}{l}\text { Silicium } \\
\text { dioxide }\end{array}$ & 31.3 & 2.2 & 88.0 & 36.2 & 1.0 & 108.7 & 29.8 & 0.9 & 81.4 & 28.3 & 2.3 & 55.3 & 35.6 & 8.7 & 90.5 \\
\hline $\begin{array}{l}\text { Water } \\
\text { temperature }\end{array}$ & 18.7 & 12.6 & 23.0 & 19.7 & 13.4 & 24.3 & 19.8 & 13.1 & 24.0 & 23.2 & 15.3 & 32.0 & 23.0 & 14.8 & 32.0 \\
\hline $\mathrm{pH}$ & 9.0 & 7.4 & 10.0 & 9.1 & 7.3 & 9.9 & 9.0 & 7.3 & 9.8 & 8.8 & 7.6 & 9.7 & 8.7 & 7.3 & 10.0 \\
\hline Humidity & 69.9 & 42.1 & 78.0 & 70.1 & 54.1 & 77.8 & 49.6 & 28.8 & 76.2 & 58.5 & 50.9 & 81.4 & 61.0 & 46.7 & 79.4 \\
\hline $\begin{array}{l}\text { Organic } \\
\text { matter }\end{array}$ & 11.9 & 8.5 & 15.5 & 13.3 & 7.6 & 25.9 & 7.4 & 2.7 & 18.5 & 15.4 & 9.7 & 25.3 & 12.6 & 10.0 & 17.9 \\
\hline
\end{tabular}

Table 2. Table of mollusk abundances at the different sites. Absolute abundance and relative abundance in relation to total mollusk abundance at each site in brackets. Absolute abundance is expressed in number of mollusks caught per hour in a $5 \mathrm{~m}^{2}$ sampling area.

Tabla 2. Tabla de abundancias de moluscos en los sitios. Entre paréntesis figura la abundancia absoluta y la abundancia relativa en relación a las abundancias de moluscos totales en el sitio. La abundancia absoluta está expresada como el número de moluscos capturados por hora en un área de muestreo de $5 \mathrm{~m}^{2}$.

\begin{tabular}{lccccc}
\hline Species & S1 & S2 & S3 & S4 & S5 \\
\hline Heleobia parchappii & 170 & 292 & 531 & 12 & 9 \\
Biomphalaria peregrina & $(55.9)$ & $(60.2)$ & $(71)$ & $(2.9)$ & $(0.8)$ \\
& 3 & 3 & 7 & 152 & 360 \\
Uncancylus concentricus & $(1)$ & $(0.6)$ & $(0.9)$ & $(37.7)$ & $(33.6)$ \\
& 59 & 73 & 37 & 65 & 220 \\
Physa acuta & $(19.4)$ & $(15.1)$ & $(4.9)$ & $(16.1)$ & $(20.5)$ \\
& 69 & 105 & 158 & 37 & 48 \\
Musculium argentinum & $(22.7)$ & $(21.6)$ & $(21.1)$ & $(9.2)$ & $(4.5)$ \\
& 0 & 0 & 0 & 61 & 263 \\
Drepanotrema heloicum & $(0)$ & $(0)$ & $(0)$ & $(15.1)$ & $(24.5)$ \\
& 1 & 1 & 0 & 44 & 62 \\
Antillorbis nordestensis & $(0.3)$ & $(0.2)$ & $(0)$ & $(10.9)$ & $(5.8)$ \\
Pomacea canaliculata & 0 & 0 & 0 & 7 & 92 \\
Omalonyx sp. & $(0)$ & $(0)$ & $(0)$ & $(1.7)$ & $(8.6)$ \\
Stenophysa marmorata & 2 & 5 & 14 & 18 & 5 \\
& $(0.7)$ & $(1)$ & $(1.9)$ & $(4.5)$ & $(0.5)$ \\
& 0 & 5 & 1 & 7 & 13 \\
& $(0)$ & $(1)$ & $(0.1)$ & $(1.7)$ & $(1.2)$ \\
\end{tabular}



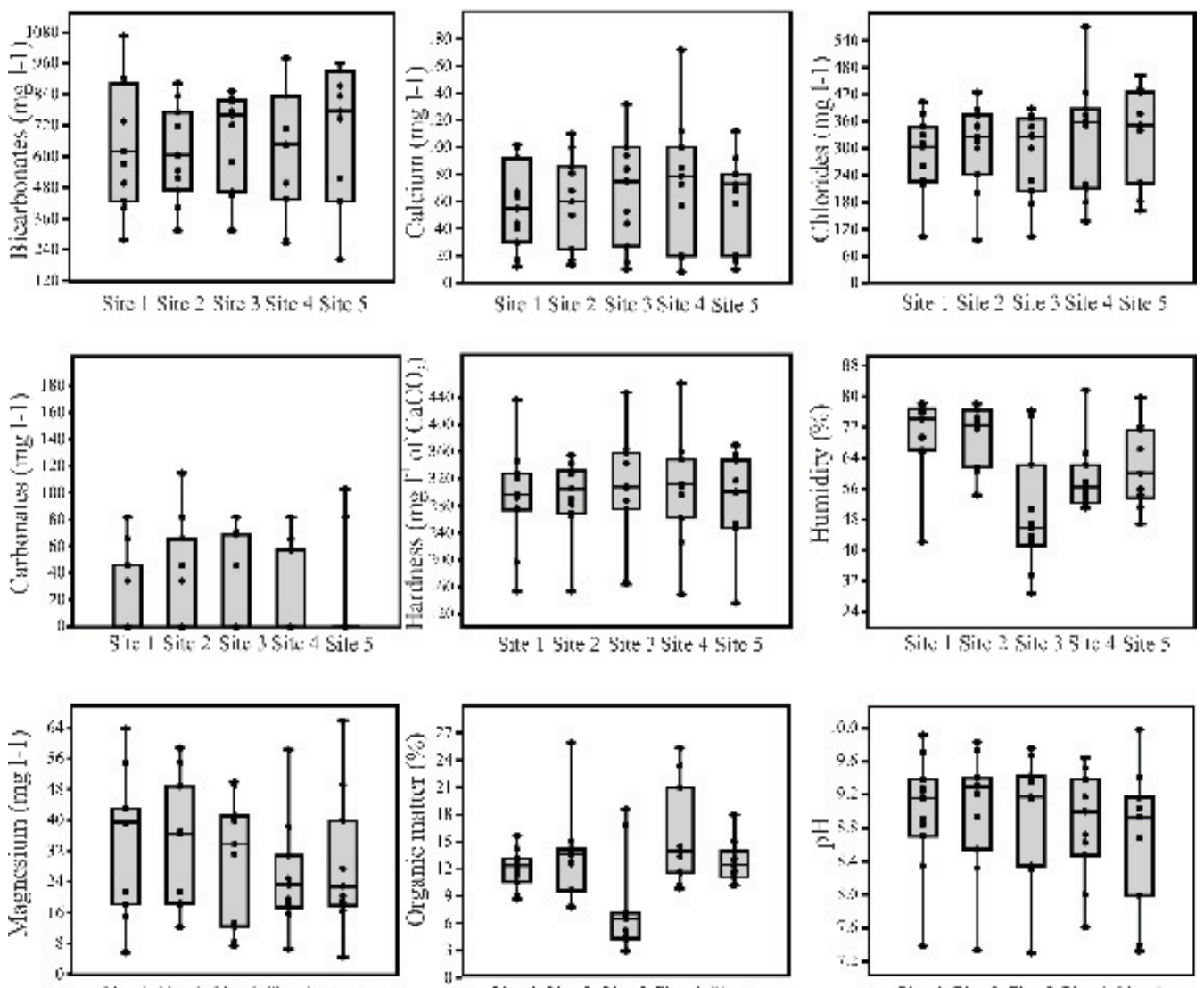

Sile I Sile I Sile 3 isile 4 Sitt:

Site I Sile ? Sile 3 Sile 4 Site 5

Sike I Sitc 2 Silz ? Site 1 Si s 5
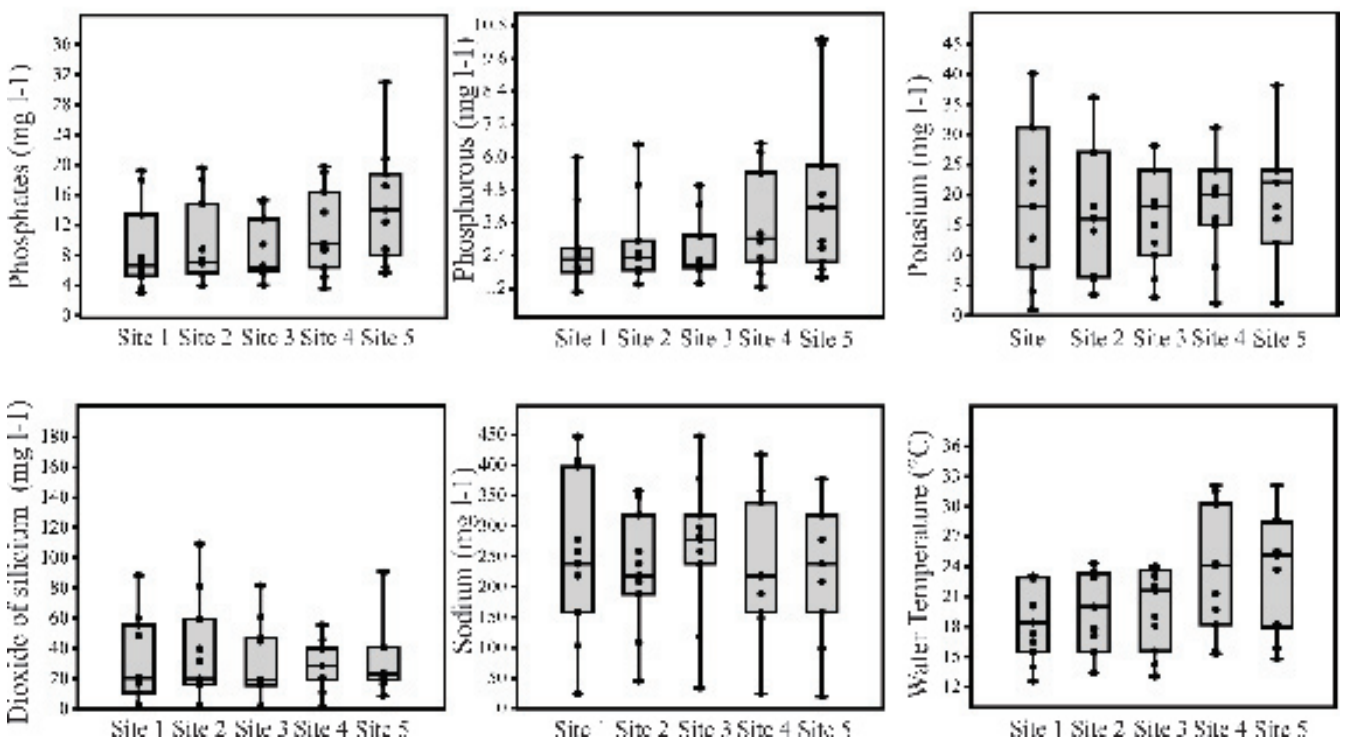

Figure 2. Box-plot of environmental variables at the sampled sites. Concentrations of ions are expressed in mg/L, humidity $(\%)$, organic content $\left(\%\right.$, estimated using the loss-on-ignition method), water temperature $\left({ }^{\circ} \mathrm{C}\right)$ and hardness (mg/L of CaCO3).

Figura 2. Box-plot de las variables ambientales en los sitios muestreados. Las concentraciones de iones están expresadas en $\mathrm{mg} / \mathrm{L}$, humedad (\%), contenido orgánico (\%), temperatura del agua $\left({ }^{\circ} \mathrm{C}\right)$ y dureza $(\mathrm{mg} / \mathrm{L} \mathrm{de} \mathrm{CaCO3).}$ 


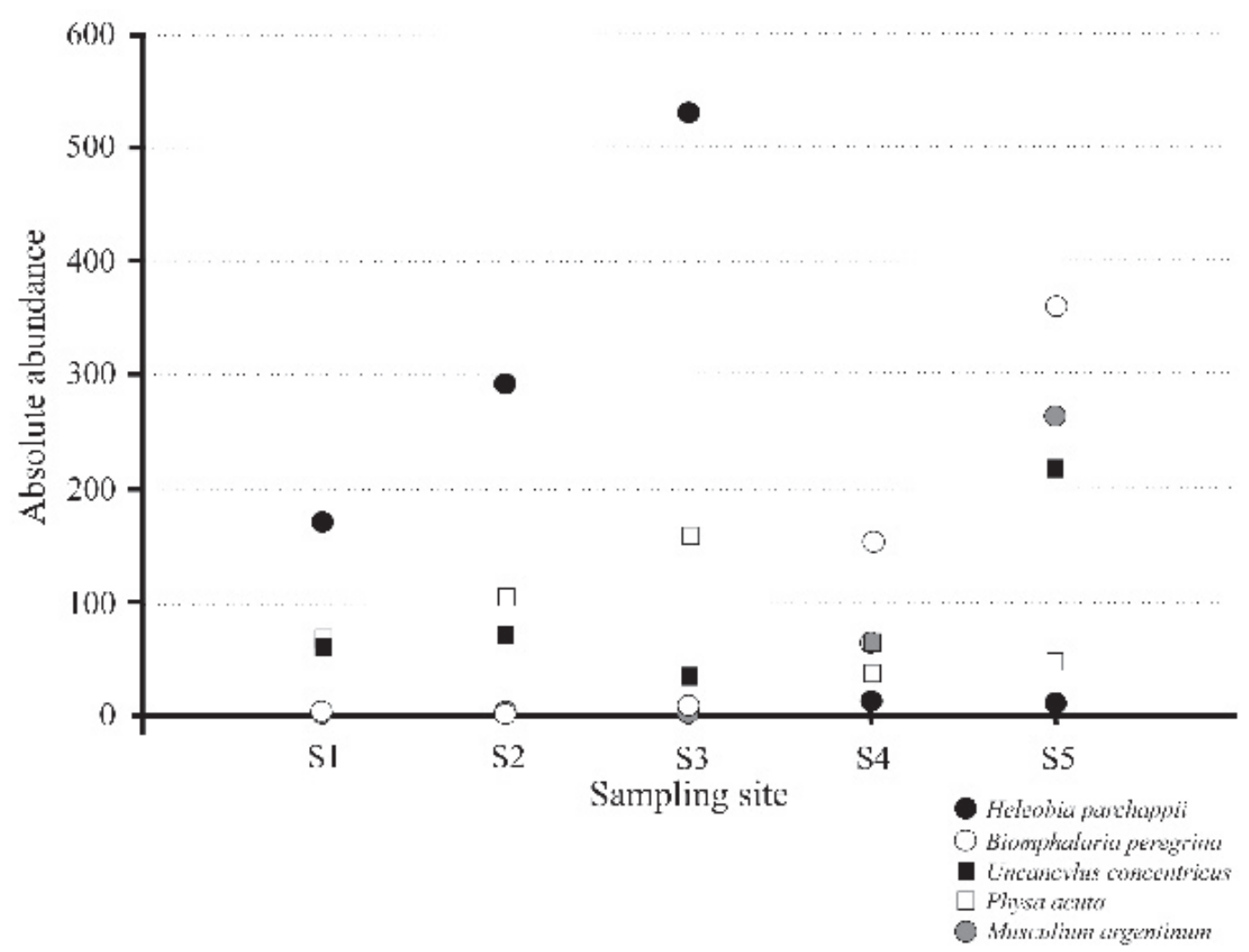

Figure 3. Number of individuals (caught per hour in a $5 \mathrm{~m}^{2}$ sampling area) of the most abundant species at the sites. Mollusk species: dark circle: Heleobia parchappii; white circle; Biomphalaria peregrina; dark square: Uncancylus concentricus; white square: Physa acuta; gray circle: Musculium argentinum.

Figura 3. Número de individuos (capturados por hora en un área de muestreo de $5 \mathrm{~m}^{2}$ ) de las especies más abundantes por sitio. Especies de moluscos: círculo oscuro: Heleobia parchappii; círculo blanco; Biomphalaria peregrina; cuadrado oscuro: Uncancylus concentricus; cuadrado blanco: Physa acuta; círculo gris: Musculium argentinum.

parchappii, Biomphalaria peregrina, Uncancylus concentricus, Physa acuta, the bivalve Musculium argentinum, Drepanotrema heloicum, Antillorbis nordestensis, Pomacea canaliculata, Omalonyx sp., and Stenophysa marmorata. Heleobia parchappii was more abundant in S1, S2 and S3 and its abundance increased since February 2015. Biomphalaria peregrina was very abundant in S4 and S5, and nearly absent in S1, S2 and S3. In November and December its abundance decreased and then it achieved three peaks during January and February, May 2015 and September 2015. Uncancylus concentricus was very abundant in all sites between August and December 2014, and during April and May 2015 in S4 and S5. Physa acuta had a peak of abundance in all sites during November 2014 and in S2 and S3 in February 2015. The bivalve $M$. argentinum had a high abundance in $\mathrm{S} 4$ and S5 between October and November 2014. Drepanotrema heloicum was very abundant in S4 during August 2014 and since May 2015 in S5. Antillorbis nordestensis had a high abundance since May 2015 in S5. Pomacea canaliculata had a peak of abundance during summer months in
S2, S3, S4 and S5. Only two or three individuals of Omalonyx sp. were recorded in S2 during summer, while in March and April were more abundant in S4 and S5. Just one individual of $S$. marmorata was found in S2 in October 2014.

Richness varied between 1 and 7, ShannonWiener diversity index between 0 and 1.54, and dominance index between 0 and 0.84 (Table 3). Mean values of the community indices such as $\mathrm{S}, \mathrm{H}$, and 1-D were not significantly different between sites, with the exception of richness between S1-S5 and S3-S5 and diversity between S3-S5 (Table 4).

Multivariate analysis performed on mollusk abundances showed significant differences between sites (PERMANOVA, $P<0.01$ ) (Table 5). Pair-wise results for sites showed $p$ values lower than 0.01 between S4 and S5 with S1, S2 and S3 respectively. Plots evidence these differences (Figure 4).

SIMPER results showed that the average similarity within each sampling site calculated by species was lower in S5 and higher in S1 
Table 3. Species richness (S), absolute abundance (n), Shannon-Wiener diversity index (H) and dominance Simpson index (1-D) for the different sites and months analyzed.

Tabla 3. Riqueza de especies (S), abundancia absoluta (n), índice de diversidad de Shannon-Wiener (H) e índice de dominancia de Simpson (1-D) para los diferentes sitios y meses analizados.

\begin{tabular}{lccccccccccccccccccccc}
\hline & \multicolumn{1}{c}{ Site 1} & \multicolumn{1}{c}{ Site 2 } & \multicolumn{1}{c}{ Site 3 } & \multicolumn{4}{c}{ Site 4} & \multicolumn{4}{c}{ Site 5 } \\
\hline & $\mathrm{S}$ & $\mathrm{n}$ & $\mathrm{H}$ & $1-\mathrm{D}$ & $\mathrm{S}$ & $\mathrm{n}$ & $\mathrm{H}$ & $1-\mathrm{D}$ & $\mathrm{S}$ & $\mathrm{n}$ & $\mathrm{H}$ & $1-\mathrm{D}$ & $\mathrm{S}$ & $\mathrm{n}$ & $\mathrm{H}$ & $1-\mathrm{D}$ & $\mathrm{S}$ & $\mathrm{n}$ & $\mathrm{H}$ & $1-\mathrm{D}$ \\
Aug. & 3 & 10 & 1.05 & 0.71 & 3 & 30 & 0.94 & 0.60 & 3 & 21 & 0.93 & 0.60 & 7 & 91 & 1.42 & 0.71 & 3 & 44 & 0.84 & 0.51 \\
Oct. & 3 & 12 & 0.57 & 0.32 & 6 & 44 & 1.19 & 0.62 & 3 & 22 & 0.89 & 0.57 & 5 & 92 & 1.07 & 0.60 & 5 & 318 & 1.03 & 0.61 \\
Nov. & 3 & 60 & 0.95 & 0.58 & 3 & 103 & 1.07 & 0.65 & 4 & 119 & 0.51 & 0.27 & 3 & 26 & 1.04 & 0.65 & 7 & 163 & 1.26 & 0.65 \\
Dec. & 4 & 30 & 1.16 & 0.66 & 3 & 37 & 1.09 & 0.68 & 3 & 40 & 0.72 & 0.43 & - & - & - & - & - & - & - & - \\
Jan. & 3 & 7 & 1.00 & 0.71 & 5 & 10 & 1.50 & 0.84 & 4 & 21 & 1.14 & 0.67 & 2 & 30 & 0.15 & 0.07 & 2 & 46 & 0.10 & 0.04 \\
Feb. & 2 & 20 & 0.61 & 0.44 & 5 & 25 & 1.47 & 0.77 & 5 & 70 & 1.23 & 0.66 & 1 & 9 & 0.00 & 0.00 & 2 & 50 & 0.10 & 0.04 \\
Mar. & 3 & 29 & 0.64 & 0.36 & 1 & 57 & 0.00 & 0.00 & 2 & 123 & 0.05 & 0.02 & 7 & 37 & 1.54 & 0.74 & 5 & 33 & 1.37 & 0.72 \\
Apr. & 2 & 53 & 0.16 & 0.07 & 5 & 19 & 1.04 & 0.53 & 3 & 84 & 0.13 & 0.05 & 4 & 44 & 0.87 & 0.45 & 4 & 58 & 1.01 & 0.55 \\
May & 4 & 45 & 0.39 & 0.17 & 2 & 13 & 0.62 & 0.46 & 3 & 115 & 0.10 & 0.03 & 5 & 18 & 1.49 & 0.80 & 5 & 118 & 1.30 & 0.69 \\
Jun. & 3 & 23 & 0.83 & 0.55 & 2 & 52 & 0.10 & 0.04 & 3 & 84 & 0.13 & 0.05 & 2 & 9 & 0.69 & 0.56 & 5 & 62 & 1.24 & 0.64 \\
Sep. & 2 & 15 & 0.39 & 0.25 & 2 & 95 & 0.10 & 0.04 & 1 & 49 & 0.00 & 0.00 & 6 & 47 & 1.40 & 0.72 & 6 & 180 & 1.55 & 0.77 \\
\hline
\end{tabular}

Table 4. Mean differences of diversity indexes between sites. Significant differences at $\alpha=0.05$ are indicated with a*.

Tabla 4. Diferencia de medias en los índices de diversidad entre sitios. Las diferencias significativas a un $\alpha=0.05$ se indican con un *.

\begin{tabular}{cccc}
\hline Comparison & $\begin{array}{c}\text { Richness } \\
(\mathrm{S})\end{array}$ & $\begin{array}{c}\text { Diversity } \\
\left(\mathrm{H}^{\prime}\right)\end{array}$ & $\begin{array}{c}\text { Dominance } \\
(1-\mathrm{D})\end{array}$ \\
\hline S1-S2 & 0.50 & 0.52 & 0.73 \\
S1-S3 & 0.81 & 0.32 & 0.23 \\
S1-S4 & 0.08 & 0.19 & 0.41 \\
S1-S5 & $0.01^{*}$ & 0.14 & 0.43 \\
S2-S3 & 0.75 & 0.18 & 0.18 \\
S2-S4 & 0.36 & 0.55 & 0.67 \\
S2-S5 & 0.19 & 0.51 & 0.84 \\
S3-S4 & 0.16 & 0.06 & 0.08 \\
S3-S5 & $0.05^{*}$ & $0.04^{*}$ & 0.08 \\
S4-S5 & 0.91 & 0.95 & 0.93 \\
\hline
\end{tabular}

Table 5. PERMANOVA and pair-wise PERMANOVA results for mollusk abundances among sites. Significant differences at $\alpha=0.05$ are indicated with a *

Tabla 5. Resultados del PERMANOVA y de los PERMANOVA parciales para las abundancias de moluscos entre sitios. Las diferencias significativas a un $\alpha=0.05$ se indican con un *

\begin{tabular}{lccccc}
\hline Source & df & SS & MS & Pseudo F & $P$ (perm) \\
Site & 4 & 45097 & 11274 & 7.5242 & $0.001^{*}$ \\
Residuals & 48 & 71923 & 1498.4 & & \\
Total & 52 & $1.1702 E 5$ & & & \\
\hline
\end{tabular}

\begin{tabular}{lcc}
\hline Groups & $\mathrm{t}$ & $P($ perm $)$ \\
\hline S1, S2 & 0.73 & 0.688 \\
S1, S3 & 1.43 & 0.117 \\
S1, S4 & 3.12 & $0.001^{*}$ \\
S1, S5 & 3.28 & $0.001^{*}$ \\
S2, S3 & 0.90 & 0.454 \\
S2, S4 & 3.39 & $0.001^{*}$ \\
S2, S5 & 3.48 & $0.001^{*}$ \\
S3, S4 & 3.44 & $0.001^{*}$ \\
S3, S5 & 3.50 & $0.001^{*}$ \\
S4, S5 & 1.12 & 0.248 \\
\hline
\end{tabular}

with respect to the rest of the sites, and the highest dissimilarity values were found when compared S4 and S5 with S1, S2 and S3 (Table 6). The species which mostly contributed to the similarity within each sampling site, and thus typify their mollusk assemblages were $H$. parchappii, $U$. concentricus and P. acuta in S1, S2 and S3, constituting about 98.58, 97.23 , and 97.71 cumulative \% of the total

Table 6. SIMPER average similarity (greyed) and average dissimilarity calculated on the base of mollusk composition among sites.

Tabla 6. Resultados del análisis de SIMPER. Similitud (sombreada) y disimilitud calculadas en base a la composición de moluscos entre sitios.

\begin{tabular}{cccccc}
\hline & S1 & S2 & S3 & S4 & S5 \\
\hline S1 & 53.92 & & & & \\
S2 & 44.36 & 54.27 & & & \\
S3 & 49.87 & 46.15 & 52.21 & & \\
S4 & 73.60 & 75.82 & 79.07 & 40.90 & \\
S5 & 76.10 & 77.39 & 80.49 & 59.81 & 40.47 \\
\hline
\end{tabular}

Table 7. DISTLM results of the relationship between environmental variables and mollusk abundances. Significant differences at $\alpha=0.05$ are indicated with $a^{*}$.

Tabla 7. Resultados de DISTLM de la relación entre las variables ambientales y las abundancias de moluscos. Las diferencias significativas a un $\alpha=0.05$ se indican con un*.

\begin{tabular}{lccc}
\hline Variable & SS & Pseudo-F & $P$ \\
\hline Carbonates & 3341.2 & 1.499 & 0.171 \\
Bicarbonate & 6951.2 & 3.221 & 0.022 \\
Chlorides & 7465.4 & 3.475 & 0.013 \\
Hardness & 3830.8 & 1.726 & 0.129 \\
Calcium & 2794.8 & 1.248 & 0.289 \\
Magnesium & 4351.3 & 1.969 & 0.098 \\
Phosphates & 7932.6 & 3.708 & $0.011^{*}$ \\
Phosphorous & 14350.0 & 7.128 & $0.001^{*}$ \\
Sodium & 6340.1 & 2.921 & 0.034 \\
Potassium & 4451.4 & 2.016 & 0.070 \\
Silicium dioxide & 7001.1 & 3.245 & 0.015 \\
Temperature & 16324.0 & 8.267 & $0.001^{*}$ \\
pH & 13883.0 & 6.865 & $0.001^{*}$ \\
Humidity & 4369.2 & 1.978 & 0.092 \\
Organic matter & 2985.0 & 1.335 & 0.255 \\
\hline
\end{tabular}




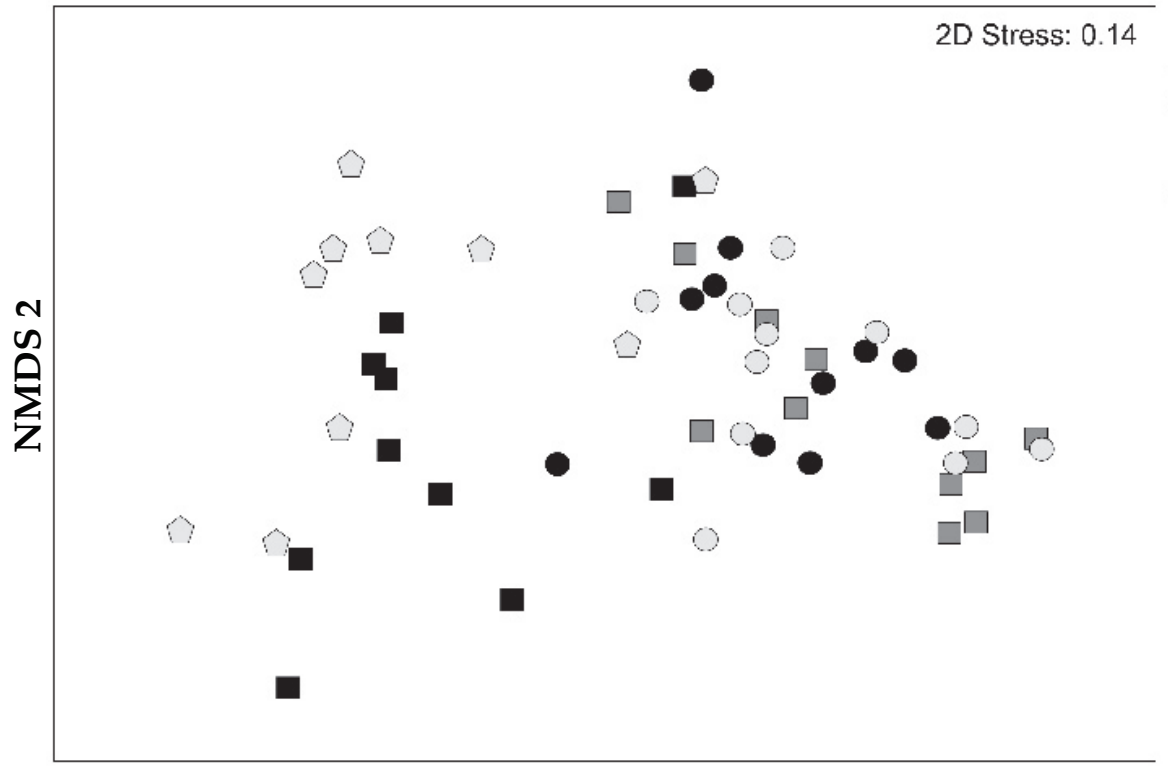

NMDS 1
Figure 4. NMDS based on mollusk abundances at each site among site.

Figura 4. NMDS basado en las abundancias de moluscos en cada sitio. similarity respectively; Heleobia parchappii was the dominant species. In S4 and S5 B. peregrina, $U$. concentricus, $P$. acuta, and $M$. argentinum represented 96.1 and $89.63 \%$, respectively, being $B$. peregrina the dominant species. Besides, D. heloicum contributed with $4.91 \%$ to the total similarity of S5. The different composition in these two groups reflects the difference between sites found in PERMANOVA analysis. The marginal test of the DISTLM procedure highlighted that mollusk abundances were significantly related to four environmental variables: phosphorous, temperature, $\mathrm{pH}$ and phosphates (Table 7).

\section{DISCUSSION}

All mollusk species found in this study were previously recorded in other studies conducted in the southeastern pampas. The two dominant species, $H$. parchappii and B. peregrina, were also commonly found as dominant species in Pampean freshwater systems (Tietze et al. 2010). The number of mollusk species found was higher than in previous studies performed in the same lake (two and eight in Tietze and De Francesco 2010 and 2012, respectively). The differences between the three studies can be consequence of the sampling frequency, which was just one sample in the first case, seasonal sampling in the second case and monthly samples in the present contribution. For diverse taxa, as more individuals are sampled, more species will be recorded (Bunge and Fitzpatrick 1993; Gotelli and Colwell 2001).
As it was explained above, mollusk species that dominate the lake were species commonly found in Pampean freshwater systems (Tietze and De Francesco 2010, 2012). Yet, the structure of mollusk communities between microenvironments showed some significant differences. Despite richness, diversity and dominance was similar between sites, the faunistic composition was different depending on the microhabitats sampled. While colonization and water chemistry can be important to determine snail distribution across a large biogeographic scale, available evidence suggests that disturbance and biotic factors are more important to determine the distribution and abundance of snails among and within water bodies (Lodge et al. 1987).

The different mollusk composition found between groups of sites S1, S2, S3 and S4, $\mathrm{S} 5$, is probably related to the characteristics at microhabitat scale. Sites 1 to 3 were deeper sites, dominated mainly by emergent macrophytes. In fact, S3 showed lower values of organic matter probably due to the lower macrophyte cover in the site. In contrast, S4 and S5 exhibited higher temperature, phosphorous and phosphates, and lower $\mathrm{pH}$, conditions that may be related to the lower depth and higher diversity of macrophytes in the sites. These two sites were dominated by free floating plants, submerged macrophytes, and transitional vegetation, however, emergent rooted macrophytes were also present. Phosphorus concentration may be explained by the decaying of macrophytes 
that act as an internal phosphorus source for the lake and add considerable quantities of phosphorus to the water (Granéli and Solander 1988). The decaying organic matter also produces a decrease in $\mathrm{pH}$ values, acidifying the medium. The discussed differences between microenvironments are influencing the composition of mollusk assemblages. However, other biological factors (as predation), may also be important to determine the composition of mollusk assemblages, which were not considered in this study and deserve further investigation.

Mollusk species composition varied between sites, probably related to their ecological requirements. Sites 1, 2 and 3 were dominated by $H$. parchappii, $P$. acuta and $U$. concentricus. Heleobia parchappii is a plastic species with a wide range of distribution in Argentina and very abundant in the Pampean Ecoregion (Gaillard and de Castellanos 1976; Castellanos and Landoni 1995). Indeed, it has been found living in freshwater environments of the region varying from oligohaline sites (Tietze and De Francesco 2010, 2012, 2017) to hipersaline sites (De Francesco and Isla 2003). Despite being very widespread in freshwater environments, its distribution within the same freshwater body has not been focus of researches yet. Uncancylus concentricus is a pulmonate species that lives attached to a firm substrate (macrophytes, rocks, artificial substrates, among others), and its abundance is probably related to the dominance of emergent macrophytes in these sites. Physa acuta is an invader species also very common in the Pampean ecoregion. This snail has a lifecycle that is characterized by high proliferation rates, high passive dispersal capacities and high tolerance to polluted water (Bernot et al. 2005). The presence and high abundance of $H$. parchappii and P. acuta, both plastic species that are very tolerant to different environmental conditions in the area, in sites 1 to 3 , and almost absence in site 4 and 5 is striking. Studies considering biological variables as predation, competition, parasitism and other environmental factors would be necessary to depict the situation.

Sites 4 and 5 were dominated by B. peregrina and the bivalve $M$. argentinum, and were common two planorbid species (D. heloicum and $A$. nordestensis), which were nearly absent in sites 1 to 3 . These two sites were characterized by lower depth and higher vegetation cover; the low depth favor higher water temperatures and lower $\mathrm{pH}$ values at this site. Depth and vegetation are variables that have been previously mentioned as important in explaining mollusk distribution. Macrophytes serve as sources of food, substrate, and buffers of current velocity (Dillon 2000). In fact, B. peregrina develops abundant populations preferably in calm waters with submerged macrophytes (Rumi 1986, 1991). Musculium argentinum is an infaunal bivalve that lives buried within the first few centimeters below the sediment-water interface with density population positively influenced by eutrophic waters and water flow (Peredo et al. 2009). In conclusion, the presence and abundance of the planorbids and the bivalve species is in accordance with the previous results found in other studies with respect to their ecology preferences.

As a summary, despite the enormous amount of research regarding the factors that determine diversity of freshwater mollusk species worldwide, little is actually known from South American habitats. At the same time, there are no studies regarding the mechanisms that determine species coexistence, share of resources, predator effects and inter- and intraspecific competition (Chase et al. 2001). This study contributes to the knowledge of the freshwater mollusk assemblages in Pampean shallow lakes, reflecting their patchiness in these systems, where environmental factors partially explain part of the local distribution within thelake, but where some other biological variables would be also needed for depict the distribution of these species at a microhabitat scale. Our results are in accordance with a hierarchical model presented by Lodge et al. (1987), which proposed that physicochemical factors explain freshwater snail distribution within a region, but disturbance and food selection seems to be determining variables within a waterbodies scale.

Acknowledgements. We thank Pedro Urrutia for allowing us to work in Nahuel Rucá and Gustavo Bernava for chemical analysis. E. Tietze, P. A. Cristini and S. I. Grondona are members of Consejo Nacional de Investigaciones Científicas y Técnicas (CONICET). This work was supported by Agencia Nacional de Investigación Científica y Tecnológica (PICT 2013-0564). 


\section{REFERENCES}

Anderson, M. J. 2001. A new method for non-parametric multivariate analysis of variance. Austral Ecology 26:32-46.

Anderson, M. J. 2005. PERMANOVA: A Fortran Computer Program for Permutational Multivariate Analysis of Variance, Auckland, New Zealand Department of Statistics, University of Auckland.

Anderson, M. J., R. N. Gorley, and K. R. Clarke. 2008. PERMANOVA+ for PRIMER: Guide to Software and Statistical Methods, PRIMER-E, Plymouth, UK. Pp. 214.

APHA. 1992. Standard methods for the examination of water and wastewater. APHA, Washington, DC.

Bernot, R. J., E. E. Kennedy, and G. A. Lamberti. 2005. Effects of ionic liquids on the survival, movement, and behavior of the freshwater snail, Physa acuta. Environmental Toxicology and Chemistry 24:1759-1765.

Bunge, J., and M. Fitzpatrick. 1993. Estimating the number of species; a review. Journal of American Statistical Association 88:364-373.

Castellanos De, Z. A., and D. Fernández. 1976. Mollusca, Gasteropoda, Ampullariidae. in: R. A. Ringuelet (dir.). Fauna de Agua Dulce de la República Argentina 15:1-33. Fundación para la Educación, la Ciencia y la Cultura, Buenos Aires.

Castellanos De, Z. A., and M. C. Gaillard. 1981. Mollusca, Gasteropoda, Chilinidae. in: R.A. Ringuelet (dir.) Fauna de Agua Dulce de la República Argentina 15:19-52. Fundación para la Educación, la Ciencia y la Cultura, Buenos Aires.

Castellanos De, Z. A., and N. Landoni. 1995. Mollusca Pelecypoda y Gasteropoda. Pages 759-781 in E. Lopretto and G. Tell (eds.). Ecosistemas de Aguas Continentales. Ediciones Sur, La Plata

Chase, J. M., W. G. Wilson, and S. A. Richards. 2001 Foraging trade-offs and resource patchiness: theory and experiments with a freshwater snail community. Ecology Letters 4:301-312.

Clarke, K. R. 1993. Non-parametric multivariate analysis of changes in community structure. Australian Journal of Ecology 18:117-143.

Clarke, K. R., and R. M. Warwick. 2001. Change in marine communities: an approach to statistical analysis and interpretation, 2nd edition. PRIMER-E, Plymouth. Pp. 172.

Cummins, R. H. 1994. Taphonomic processes in modern freshwater molluscan dead assemblages: Implications for the freshwater fossil record. Palaeogeography, Palaeoclimatology, Palaeoecology 108:55-73. DOI: 10.1016/00310182(94)90022-1.

Cummins, K. S., and A. E. Bogan. 2006. Unionida: freshwater mussels. Pp. 313-326 in (C. F. Sturm, T. A. Pearce and A. Valdés (eds.). The Mollusks: a guide to their study, collection, and preservation. Pittsburgh: American Malacological Society.

De Francesco, C. G., and F. I. Isla. 2003. Distribution and abundance of hydrobiid snails in a mixed estuary and a coastal lagoon, Argentina. Estuaries 26(3):790-797.

De Francesco, C. G., E. Tietze, and P. A. Cristini. 2013. Mollusk successions of Holocene shallow-lake deposits from the southeastern pampa plain, Argentina. Palaios 28:851-862.

Dillon, R. T. Jr. 2000. The Ecology of Freshwater Molluscs. Cambridge University Press, Cambridge.

Diovisalvi, N., V. Y. Bohn, M. C. Piccolo, G. M. E. Perillo, C. Baigún, and H. E. Zagarese. 2015. Shallow lakes from the central plains of Argentina: an overview and worldwide comparative analysis of their basic limnological features. Hydrobiologia 752:5-20.

Fagundes, C. K., E.R. Behr, and C. B. Kotzian. 2008. Diet of Iheringichthys labrosus (Siluriformes, Pimelodidae) in Ibicuí River, Southern Brazil. Iheringia, Série Zoologia 98:1-6.

Feijoó, C. S., and R. J. Lombardo. 2007. Baseline water quality and macrophyte assemblages in Pampean streams: A regional approach. Water Research 41:1399-1410.

Fernández, D. 1981a. Mollusca, Gasteropoda, Physidae. In: R. A. Ringuelet (dir.). Fauna de agua dulce de la República Argentina 15:83-98. Fundación para la Educación, la Ciencia y la Cultura, Buenos Aires.

Fernández, D. 1981b. Mollusca, Gasteropoda, Ancylidae. In: R. A. Ringuelet (dir.). Fauna de agua dulce de la República Argentina 15:99-114. Fundación para la Educación, la Ciencia y la Cultura, Buenos Aires.

Fernández Cirelli, A., and P. Mirezky. 2004. Ionic relations: a tool for studying hydrogeochemical processes in Pampean shallow lakes (Buenos Aires, Argentina). Quaternary International 114:113-121.

Gaillard, M. C., and Z. A. De Castellanos. 1976. Mollusca, Gasteropoda, Hydrobiidae. In: R. A. Ringuelet (dir.). Fauna de agua dulce de la República Argentina 15:1-40. Fundación para la Educación, la Ciencia y la Cultura, Buenos Aires.

García, A., D. J. Hoeinghaus, J. P. Vieira, K. O. Winemiller, D. M. L. Motta-Márquez, and M. A. Bemvenuti. 2006. Preliminary examination of food web structure of Nicola Lake (Taim hydrological system, south Brazil) using dual $\mathrm{C}$ and N stable isotope analysis. Neotropical Ichthyology 4:279-284.

Geraldi, A. M., M. C. Piccolo and G.M. E. Perillo. 2011. El rol de las lagunas bonaerenses en el paisaje pampeano. Ciencia Hoy 21: 9-14.

Gotelli, N. J., and R. K. Colwell. 2001. Quantifying biodiversity: procedures and pitfalls in the measurement and comparison of species richness. Ecology Letters 4:379-391.

Granéli, W., and D. Solander. 1988. Influence of aquatic macrophytes on phosphorus cycling in lakes. Hydrobiologia 170:245-266.

Horsák, M., M. Hájek, L. Tichý, and L. Jur*čková. 2007: Plant in- dicator values as a tool for land mollusc autecology 
assessment. Acta Oecologica 32:161-171.

Lodge, D. M., K. M. Brown, S. P. Klosiewsky, R. A. Stein, A. P. Covich, B. K. Leathers, and C. Bronmark. 1987. Distribution of freshwater snails: spatial scale and the relative importance of physicochemical and biotic factors. American Malacological Bulletin 5:73-84.

Magurran, A. E. 1988. Ecological diversity and its measurement. Croom Helm, New South Wales. Pp. 179.

Maltchik, L., C. Stenert, C. B. Kotzian, and D. Pereira. 2010. Responses of freshwater mollusks to environmental factors in Southern Brazil wetlands. Brazilian Journal of Biology 70:473-482.

Martello, A. R., C. B. Kotzian, and M. G. Simões. 2006. Quantitative fidelity of Recent freshwater mollusk assemblages from the Touro Passo River, Rio Grande do Sul, Brazil. Iheringia Série Zoologia, 96:453-465. DOI: 10.1590/S007347212006000400010 .

Martín, P. R., A. L. Estebenet, and N. J. Cazzaniga. 2001. Factors affecting the distribution of Pomacea canaliculata (Gastropoda: Ampullariidae) along its southernmost natural limit. Malacologia 43:13-23.

McMahon, R. F., and A. E. Bogan. 2001. Mollusca: Bivalvia. Pp. 331-429 in J. H. Thorp and A. P. Covich (eds.). Ecology and classification of North American Freshwater Invertebrates. San Diego: Academic Press.

Peredo, S., E. Parada and P. Jara-Seguel. 2009. Life histories and dynamics of stream and lacustrine populations of Musculium argentinum (D'Orbigny, 1842) (Bivalvia: Sphaeriidae) from Southern Chile. Malacologia 51:29-38.

Quirós, R., and E. Drago. 1999. The environmental state of Argentinean lakes: an overview. Lakes and Reservoirs: Research and Management 4:55-64.

Rumi, A. 1986. Estudio morfológico, taxonómico y bio-ecológico de planórbidos argentinos. Doctoral Thesis. Universidad Nacional de La Plata, La Plata, Argentina.

Rumi, A. 1991. La familia Planorbidae Rafinisque, 1815 en la República Argentina. in: Z. A. de Castellanos (ed.) Fauna de Agua Dulce de la República Argentina 15:3-51. Programa de Fauna de Agua Dulce Museo de La Plata, Buenos Aires.

Simpson, E. 1949. Measurement of diversity. Nature 163:688.

Tietze, E., and C. G. De Francesco. 2010. Environmental significance of freshwater mollusks in the Southern Pampas, Argentina: to what detail can local environments be inferred from mollusk composition? Hydrobiologia 641:133-143. DOI: $10.1007 / \mathrm{s} 10750-009-0072-7$.

Tietze, E., and C. G. De Francesco. 2012. Compositional fidelity of subfossil mollusk assemblages in stream and lakes of the southeastern pampas, Argentina. Palaios 27:401-414.

Tietze, E., and C. G. De Francesco. 2017. Compositional fidelity and taphonomy of freshwater mollusks from three pampean shallow lakes of Argentina. Ameghiniana 54:208-223.

Viglizzo, E. F., F. C. Frank, L. V. Carrenõ, E. G. Jobbágy, H. Pereyra, J. Clatt, D. Pincén, and M. F. Ricard. 2011. Ecological and environmental footprint of 50 years of agricultural expansion in Argentina. Global Change Biology 17:959-973. 